https://doi.org/10.18485/kud_kiaz.2019.ch33

\author{
Мухтар Иманов \\ Действительный член Национальной \\ Академии Наук Азербайджана \\ Директор института Фольклора НАНА
}

\title{
АРХАИЧЕСКАЯ СУЩНОСТЬ СМЕХА В АЗЕРБАЙДЖАНСКОМ ФОЛЬКЛОРЕ
}

\section{SUMMARY}

According to the mythological thought the laugh is the symbol of birth and life-giving. It is not coincidence that one of the mythological characters connecting laugh is the Sun. In the thought of the ancient human the rise of the Sun means the laugh of the Sun and this laugh becomes the reviving of the nature. The formation of the flowers from the laugh of the fairy girls in the tales is one of the characteristic indicators of the birth and life-giving.

We are a witness of the cult level of laugh in the epos. One can meet the signs of laugh cult together with bird, animal cults in the epos "Dede Gorgud". The indicator of the laugh cult is that in the same epos the sacred human like as Dede Gorgud is presented with the humoristic language as trickster in some opportunities; the comic similarity shows the magic influence to the head hero, it carries the function of increasing its strength.

In Azerbaijan folklore the mythological essence of laugh creates the unity with the aesthetic unity. Unlike the satiric laugh in the written literature the laugh in folklore carries just the life-giving essence, not the "fatal" essence.

Key words: myth, the cult of laugh, the magic influence, tale, epos, "fatal" laugh, the life-giving laugh. 
Определение специфической сущности комизма в фольклоре требует акцентирования внимания на архаических корнях смеха. Следует принимать во внимание, что в системе архаичного мировоззрения смех, в первую очередь, был связан с образом Солнца. Древний человек, пугающийся заката солнца, радуясь его восходу, называл тьму злом, свет - добром. Так как человек восход солнца воспринимал как процесс смеха, солнце, постепенно превратившись в символ смеха, отобразилось в нашей историко-мифологической памяти в качестве смеющейся, улыбающейся сущности. Результатом этого является то, что в песне «Году-Году» восход солнца нашел свое отражение в значении смеха, а закат солнца - плача.

В сущности выражения смехового содержания света лежит вопрос рождения. Человек, желающий пением песни «Году-году» добиться восхода солнца, плодородия земли, прежде всего, ищет в поиске «смеха» дня/солнца. «Смех» дня/солнца необходим именно для повышения плодородия, возрождения жизни и сотворения. Человек, смотрящий на «смех» солнца/ дня как на источник рождения, возрождения начинает видеть в смехе символ жизненности, и это символическое значение смеха находит свое отображение и в фольклоре. В сказках от смеха красавиц необычного происхождения появляются цветы; с помощью смеха удается спасти принцессу от тяжелой болезни или падишаха от смерти.

Смешное слово, смешная игра в древности считались важным средством магического воздействия на землю. Забавные песни, что исполнялись при наступлении весны, и показываемые представления типа «Коса-коса» служили именно цели «умиротворить» землю, стать помощником ее «беременности». Идентичную функцию носили древние слова саячи и представления саячи. Наши предки, желающие добиться прироста в животноводстве, считали важным петь слова саячи комического содержания и давать представления саячи.

Существует неразрывная связь между магической сущностью смеха и его эстетической природой. Народ, 
считающий смех магическим средством для достижения рождения и возрождения, строит комические фольклорные тексты на основе идеи жизнеутверждения. Характер комического конфликта в фольклоре ясно показывает жизнеутверждающее содержание смеха в фольклорных текстах, то, что разоблачение какой-либо силы вовсе не является ведущей чертой для народного смеха. Представление среднего мира, встречаемое в тюркской мифологии, сохраняет свои следы и в народном смехе. В образцах комического фольклора имеет место конфликт не между кардинально отличающимися положительным и отрицательным полюсами, а именно между сторонами, стоящими на серединных позициях. В сказках, повествующих о животных, борьба проявляется больше между коварным и разиней, чем между добром и злом, и действия животных основываются не на нормах морали, а «животной свободе». Как в комических сказках и анекдотах падишах, кази, купец и другие образы представлены в облике деспота, скупца и глупца, так и Плешивый, Молла Насреддин, Бахлул Даненде и др. главные герои также не считаются воплощением положительности. Комические фигуры, обманывающие представителей как высшего, так и низшего сословия, вместить в рамки «обязательного добра» не получается. Позиции добра и зла в образцах комического фольклора основательно отличаются от положений в некомических фольклорных образцах. Преграды между добром и злом в образцах комического фольклора значительно уменьшаются, плохое смешивается с хорошим, и отделить их друг от друга становится не так уж и легко. Смешение добра со злом, плохого с хорошим проявляется как признак, в целом характерный для народного смеха.

Поскольку фольклорные образцы о Безбородом, Плешивом, Молла Насреддине и Бахлуле Даненде представляют собой продукт коллективного творчества, поиски в этих образцах критикующей личности и критикуемой модели мира не состоятельны. Так как в народном твор- 
честве критикующий индивид представляет собой часть критикуемого мира. Безбородый, Плешивый, Молла Насреддин и Бахлул Даненде больше смеются вместе с окружающими, чем над ними. Совместный смех критикующего вместе с критикуемым в народном смехе по своему происхождению тесно связан с праздничными обрядами. Если при показе на праздничных весельях народных драм количество зрителей частично превосходит число участников из народа в других формах выражения народных празднеств, то это соотношение носит относительный характер. Все в одно и то же время становятся исполнителями и зрителями. Не только фигляры, скоморохи, фокусники, все смеются в той или иной степени шутят и играют. Проявляющаяся в повседневной жизни официальность и регламентированное поведение на праздничных весельях устраняются, радость, восторг, свобода господствуют на веселье. Атмосфера настоящего праздника возникает именно благодаря этой внутренней свободе.

В более живом, более горячем проведении праздничного веселья, где все присутствующие в равной степени вольны, естественно, велика роль фигляров. Эти люди, в повседневной жизни известные и любимые благодаря своей смешной речи и поступкам, на праздничных весельях насмехаются над различными явлениями природы и общества. Фигляры, в смешной форме воспроизводящие в представлении «Коса-коса» уход зимы и приход весны, также превращают в объект критики бека, хана, купца, моллу, кази, пахаря, жнеца, сапожника, пастуха... Фигляры вовсе не выделяют себя из рядов объектов критики. Один из них кидает реплики, раскрывающие недостатки другого, или же какой-либо фигляр, рассказывая о случившемся с ним, раскрывает свои изъяны и заставляет народ смеяться на своими (фигляра) глупыми действиями.

Независимо от того, является ли он исторической личностью, Молла Насреддин представляет собой характерный образ фигляра, фокусника и скомороха. Где 
бы он ни был - дома, в магазине, на базаре, на застолье, перед власть имущими, даже в моменты, когда едет на ишаке, встречает медведя в лесу - Молла Насреддин является фигляром, фокусником и скоморохом. И поэтому несложно представлять анекдоты о Молле Насреддине как неотъемлемую часть народного празднества. Как и фигляры на праздничном веселье, и Молла Насреддин находится среди народа, вместе с ним. К тому же в понимание народа, наряду с женой и детьми, родней и соседями, друзьями и знакомыми Моллы Насреддина, вхожи и власть имущие. Молла Насреддин, смеясь над женой и детьми, родней и соседями, друзьями и знакомыми, смеется и над власть имущими. Смеясь и над первыми, и над вторыми, Молла Насреддин смеется и над своими, и над собой. Поэтому не оправдывают себя поиски в этом смехе оттенков враждебности. Молла Насреддин и люди, над которыми он насмехается и которых смешит, составляют единый организм. Все забавные события происходят внутри этого организма. Так как проявляют себя в пределах одного организма, честный не отвергает вора, щедрый - скупого, справедливый - несправедливого, младенец - старика, здоровье - болезнь, жизнь - смерть, наоборот, они дополняют друг друга. Как в сказках о животных и представлении «Коса-коса», и в анекдотах о Молле Насреддине смерть является одной из рядовых, обычных тем для смеха и высмеивания. В насмехании Моллы Насреддина над смертью (в жевании жвачки «мертвым» Моллой, поднятии головы во время нахождения в гробу) скрывается вера, идея и философия о том, что «смерть является одним из средств перерождения».

В образе Плешивого проглядываются признаки добрых сверхъестественных сил, демонических существ и златовласых героев. А общей чертой, делающей возможным отображение в одном образе указанных мифологических источников, является связь каждого из них с потусторонним миром. Богатырство златовласого героя, положитель- 
ное влияние доброжелательных сверхъестественных сил на природу и коварство черта, найдя свое отображение в облике Плешивого, превращают этот образ в специфичный символ силы. Самобытность, прежде всего, заключается в умении, сменяя обличье, принять другой облик. Образ Плешивого, скрывающего истинную сущность за внешним признаком, составляет вместе с образами Безбородого и козла единую художественную систему. Как Безбородый скрывает свою эротическую силу за отсутствием волос, козел свою самцовость за маской кастратности, так и Плешивый свое богатырство прячет за маской бедности, красоту - за маской уродства.

Одна из ведущих особенностей народного смеха состоит в комическом изображении в анекдотах, гаравелли и сказках известных фольклорных героических типажей и создание на них пародий. В понимании отличия этой пародии от пародии в письменной литературе, носящей более резкое сатирическое содержание, ключевую роль имеет образ лжебогатыря. Образ лжебогатыря, встречаемый нами в игре «Канатоходец», пародируя канатоходца в забавной форме, носит функцию по обереганию его (канатоходца) от сглаза, зла. Отношения канатоходца и лжебогатыря в той или иной степени наблюдаются и в формах правитель и шут, богатырь и трус, правда и ложь, умный и глупый.

В узком понимании шут является одним из дворцовых слуг. Основная видимая работа этого слуги заключается в развлечении правителя, его поднятии настроения, когда он находится не в духе. А подтекстная функция шута заключается в том, чтобы, надев обличье правителя, привлечь к себе внимание злых духов и таким способом отвести беду, что может прийти к правителю. По этой функции образ шута созвучен образу временного (вымышленного) правителя, проявляющегося в древних обрядах различных народов.

С точки зрения исследования мотива правителя и шута более обильный материал дают анекдоты, расска- 
зывающие о приключениях Тамерлана и Моллы Насреддина. В анекдотах о Молле Насреддине самой типичной формой передразнивания Тамерлана является вхождение в образ различных дворцовых придворных. Передразнивая придворных, Молла Насреддин в действительности, пусть и косвенно, передразнивает самого Тамерлана. В моменты, когда речь заходит о придворных, мишенью для шуток снова становится Тамерлан. Как Молла Насреддин подшучивает над Тамерланом, так и Тамерлан порой подшучивает над Моллой Насреддином. Молла Насреддин критикует Тамерлана именно в рамках фамильярного отношения, превращая в объект фамильярной насмешки его тиранию, претензии на божественность, окружение себя слабыми людьми. Характерные черты параллели Тамерлан-Молла Насреддин наблюдаются и в параллелях Чингиз-хан - Майкы, Хусейн Байкара - Алишер Навои, Шах Аббас - Калнийят.

Комические образы труса и лентяя, по-разному трактуемые в фольклористике, на самом деле, представляют собой пародии на богатырские образы. Если шут в большей степени имитирует разумность правителя, то трус имитирует его богатырство. В мифологическом корне сказочных сюжетов, повествующих о лжебогатырстве трусливых людей, находится вера в пародирование героизма правителя и временную замену правителя подобным путем.

Появление трусливых и ленивых сказочных героев в качестве единого пародийного образца подтверждают и другие образцы пародии в сказках. В сказках становимся свидетелями превращения в пародийную тему, наряду с богатырством, и купечества, звездочетства, разбойничества.

В сказках, запрещенных к рассказу днем и рассказываемых как правдивые, вымышленные истории, формулы текста служат цели создать параллельность с самой сказкой. Из какой необходимости возникает параллельность «серьезных» и комических образов в фольклоре, из той же необходимости возникает параллельность текстов, 
построенных на «правде» и «лжи». Как лжебогатырь превращается в пародию богатыря истинного, так и гаравелли, построенное на вымысле, становится пародией на построенные на «реальности» сказки и эпоса. Как лжебогатырь дает толчок богатырю истинному, гаравелли комического содержания дает толчок повествованию сказок и эпосов трагического содержания.

Элементы пародии наиболее наглядно отображаются в образцах, где происходит прикидывание дурачком. Образ дурака в этом образце, как шут и лжебогатырь, представляет собой продукт раздвоения, «двойник». Прикидывающиеся дураком, превращающиеся в комический «вариант» умных людей Молла Насреддин и Бахлул Даненде, обретя большую свободу, получают возможность совершать противоречивые поступки. Войти в роль мифических героев, представляющих природу как живого человека, становиться «собеседником» луны на небе, дерева на земле, домашней птицы или же плова - это все характерные сцены совершения противоречивых поступков, игры в безумие.

Наблюдения над многих образцов Азербайджанского фольклора позволяют прийти к заключению, что комизм оказывает основательное воздействие на содержание текста и структуру героя. Сила смеха самую необычную вещь, изображенную в фольклорном тексте, образно говоря, низводя с небес до земли, приближает к человеку, предотвращая крайнюю идеализацию, привносит в текст смысловое разнообразие, обогащая его.

\section{Библиография}

Алексеев Н.А. Ранние формы религии тюркоязычных народов Сибири. Новосибирск: Наука, 1980, 318 с.

Басилов В.С. Культ святых в исламе. Москва: Мысль, 1970, 144 с.

Бахтин М.М. Творчество Франсуа Рабле и народная культура средневековья и ренессанса. Москва: Художественная Литература, $1965,528 \mathrm{c}$. 
Зеленин Д.К. Религиозно-магическая функция фольклорных сказок // Сборник статей С.Ф. Ольденбургу. Ленинград: Наука, 1934 , c. $220-249$.

Книга моего Деда Коркута / перевод академика В.Бартольда. Баку: 1999, 320 с.

Короглу / авторы подготовки и составление национального текста И.Аббаслы и Б.Абдулла, перевод художественного и научного текста И.Сеидов. Баку: Сада, 2000, 499 с.

Пропп В.Я. Исторические корни волшебной сказки. Ленинград: Изд-во Ленинградского Ун-та, 1986, 365 с.

Турсунов Е.Д. Генезис казахской бытовой сказки. Алма-Ата: Наука, 1973, 216 с.

Успенский Б.А. Царь и самозванец: самозванчество в России как культурно-исторический феномен // Художественный язык средневековья. Москва: Наука, 1982, с. 201-235.

Фрейденберг О.М. Поэтика сюжета и жанра. Москва: Лабиринт, 1997, 448 с.

\section{PЕЗЮME}

Согласно мифологическому мышлению, смех является символом рождения и животворения. Не случайно, что одним из мифологических пер-сонажей, связанных со смехом, является Солнце. В представлениях древнего человека восход означает смех Солнца, и этот смех становится возрождением природы. Расцветание цветов от смеха девушек героинь в сказках является одним из характерных показателей рождения и животворения.

Мы также являемся свидетелями поднятия смеха на уровень культа в эпосе. В эпосе «Деде Коркут» можно встретить признаки культа смеха, как и культ птиц и животных. Индикатором культа смеха является то, что в том же эпосе такой священный человек, как Деде Коркут, представлен юмористическим языком как трикстер в некоторых эпизодах; комическое сходство показывает магическое влияние на главного героя, оно выполняет функцию увеличения своей силы.

В азербайджанском фольклоре мифологическая сущность смеха объединяется с эстетической сущностью. В отличие от сатирического смеха в письменной литературе, смех в фольклоре несет только животворную сущность, а не «убийственную».

Ключевые слова: миф, культ смеха, магическое влияние, сказка, эпос, «роковой» смех, животворящий смех. 